\title{
MULTIDRUG EFFLUX SYSTEMS IN ESCHERICHIA COLI AND ENTEROBACTER CLOACAE OBTAINED FROM WHOLESOME BROILER CARCASSES
}

\author{
Maria Aparecida S. Moreira ${ }^{1 *}$; Patrícia P.C.F. Rodrigues²; Rafael S. Tomaz ${ }^{3}$; Célia A. de Moraes²
}

'Laboratório de Doenças Bacterianas, Setor de Medicina Veterinária Preventiva e Saúde Pública, Departamento de Veterinária, Universidade Federal de Viçosa, Viçosa, MG, Brasil; ${ }^{2}$ Laboratório de Microbiologia Industrial, Instituto de Biotecnologia Aplicada à Agropecuária, Departamento de Microbiologia, Universidade Federal de Viçosa, Viçosa, MG, Brasil; ${ }^{3}$ Laboratório de Genética de Microrganismos, Instituto de Biotecnologia Aplicada à Agropecuária, Departamento de Microbiologia e Departamento de Biologia Geral, Universidade Federal de Viçosa, Viçosa, MG, Brasil.

Submitted: May 17, 2008; Returned to authors for corrections: August 15, 2008; Approved: March 31, 2009.

\begin{abstract}
Members of the Enterobacteriaceae family are present in the intestines of man and animals as commensals or are important disease causing agents. Bacteria bearing multidrug efflux systems (MDR) are able to survive adverse ecological niches. Multiresistant Escherichia coli and Enterobacter cloacae isolates from wholesome broiler carcasses were investigated for the presence of MDR. Lowering of Minimal Inhibitory Concentration for antimicrobials in the presence of a proton-motive force (PMF) uncoupler was tested as a potential display of the MDR phenotype. PCR amplification of the genes encoding AcrA and AcrB, components of a MDR system was performed. Diversity of each species was ascertained by Pulsed-Field Gel Electrophoresis (PFGE) of DNA digested with endonuclease $X b a \mathrm{I}$. For all the isolates, except E. coli 1 and E. cloacae 9, lowering of MIC or of the growth rate in the presence of antimicrobials was observed, indicating a PMF dependent resistance mechanism. Expected products of DNA amplification with $a c r A B$ derived primers was obtained with all E. coli strains and with two of the five E. cloacae strains. Dendrogram generated shows diverse pulsetypes, confirming the genetic diversity among the strains. An important issue and related public health is the fact that different models and mechanisms of antimicrobial resistance are present in a small number of non-pathogenic strains and isolated from the same origin. These may be sources of resistance genes to others microorganisms, among them, pathogenic strains.
\end{abstract}

Key words: multiresistance; antimicrobials; Enterobacteriaceae; proton-motive force; diversity

\section{INTRODUCTION}

Antimicrobial agents have been broadly used in modern avian industries even though this practice is now challenged or banned in many countries $(2,6)$. Their use has spanned objectives such as prevention of diseases, growth promoting activities, and therapeutics (2). This practice has possibly caused favorable conditions for the selection, distribution, and persistence of antimicrobial-resistant bacteria (1). Commensal bacteria exposed to antimicrobial agents may have had their populations selected for a resistance trait and thus become a reservoir for potentially mobile resistance genes, capable of being transferred to pathogenic strains (3). Multidrug efflux systems (MDR) have commanded attention because a single resistance mechanism may diminish susceptibility to several therapeutic drugs $(13,25)$, allowing the survival of bacteria in their niches (23). There are currently five known families of proteins with the MDR phenotype. One of them, the Resistance Nodulation Cell Division (RND) family, is expressed in Gram-negative bacteria, and is linked to clinically significant drug resistance (23), driven by

*Corresponding Author. Mailing address: Laboratório de Doenças Bacterianas, Setor de Medicina Veterinária Preventiva e Saúde Pública, Departamento de Veterinária, Universidade Federal de Viçosa, UFV. Campus Universitário, Viçosa, MG, CEP 36570-000, Brasil. E-mail: mam583@ cornell.edu / masm@ufv.br 
proton-motive force (11). The AcrAB efflux system belongs to the RND family and is one of the primary efflux systems associated with $E$. coli; its overexpression has been reported in clinical isolates (23). Primers derived from E. coli acrAB sequences yielded positive results for PCR amplification of DNA from different strains of E. cloacae (19). E. coli and E. cloacae are important commensals or pathogens that inhabit the gastrointestinal tract of humans and animals $(10,12)$, and are thought to be important sources of antimicrobial resistance genes for both animal and human pathogens (27,30). A single population of bacteria may present different degrees of genetic diversity and also different antimicrobial resistance mechanism models.

In this study, we report the putative presence of MDRdependent antimicrobial resistance in non-pathogenic $E$. coli and $E$. cloacae in genetically diverse strains isolated from broiler carcasses. The results bear ecological relevance and were obtained at a time when growth-promoting antimicrobials, such as spectinomycin and apramycin, were still in use, a practice which is still allowed in Brazil.

\section{MATERIALAND METHODS}

\section{Bacteria}

Five $E$. coli and five E. cloacae strains were chosen from a collection of likely commensal isolates obtained from carcasses of clinically healthy broiler. Sampling was done on the processing line immediately after evisceration at an industrial slaughter facility. The isolates displayed distinct multiresistance phenotypes and included in their resistance profiles the antimicrobials spectinomycin, apramycin, nalidixic acid, cefadroxil, cephalexin, cefaclor, furazolidone, nitrofurantoin, spiramycin, tetracycline, chloramphenicol, and sulfamethoxazole/ trimethoprim. All strains were stocked at $-80^{\circ} \mathrm{C}$ in Brain and Heart Infusion, BHI (Oxoid, Basingstone, Hampshire, England), with $20 \%$ glycerol.

\section{Pulsed-field gel electrophoresis (PFGE)}

Pulsed-field gel electrophoresis was performed according to Chang and Chui (7) with slight modifications.

For each strain, the cell-agarose plugs were prepared with $10^{8} \mathrm{CFU} / \mathrm{mL}$ grown on BHI medium (Oxoid). For DNA hydrolysis, the plugs were treated with 50 units of $X b a$ I restriction enzyme (Promega, Madison, Wisconsin, USA). The plugs were one millimeter thick. Phage Lambda concatamers (Sigma, St. Louis, Missouri, USA) were used as molecular size standards. DNA fragments were separated by PFGE using the CHEF-Dr III system (Biorad laboratories) for $17 \mathrm{~h}$ at $12^{\circ} \mathrm{C}$ with an initial pulse of $2 \mathrm{~s}$ and a final pulse of $20 \mathrm{~s}$; angle $120^{\circ}$; at $6 \mathrm{~V} / \mathrm{s}$. The agarose gel was stained with ethidium bromide and photographed under ultraviolet illumination.

The PFGE pulsetypes were compared by analyzing TIFF files with Gel Pro Analyser® 3.1 (Media Cybernetics Inc).
Cluster analysis of the Dice Similarity Indexes, based on the unweighted pair group method using arithmetic averages (UPGMA), was carried out with the GENES program (9) to generate a dendrogram describing the relationship among the pulsetypes.

\section{Minimal inhibitory concentration - MIC}

The E. coli isolates were reactivated in BHI broth and incubated at $37^{\circ} \mathrm{C}$ for $16-18 \mathrm{~h}$. The cultures were diluted in BHI broth to $10^{5} \mathrm{cfu} / \mathrm{mL}$. Aliquots of $230 \mu \mathrm{l}$ of the diluted culture were added to microtiter plate wells (Nunc-Immuno ${ }^{\mathrm{TM}}$ ) with various amounts of different antimicrobials (Sigma) for a total volume of $300 \mu \mathrm{l}$ per well. The assays were carried out twice in triplicate, as were the required controls. Growth was periodically assessed spectrophotometrically in an ELISA plate reader (Titertek multiskan ${ }^{\circledast}$, Plus-MkII) at $\lambda 540 \mathrm{~nm}$. Curves were plotted with the media of the triplicates. The MIC was arbitrarily established as the minimum concentration of each antimicrobial that completely inhibited growth of the cells until two hours after the begining of the stationary phase of the control (E. coli growing in BHI) $(18,19)$.

\section{Active efflux phenotype}

The presence of active efflux for each antimicrobial was determined by comparison of the MIC in the presence and absence of carbonyl cyanide m-chlorophenylhydrazone-CCCP (Sigma) $(18,20)$. The highest CCCP concentration that would not affect the growth rate of each isolate was determined and used in the experiments.

\section{PCR amplifications of the acrA and acrB genes}

Specific primers for amplification of the genes $a c r A$ and $a c r B$ were constructed using $E$. coli $\mathrm{K} 12$ genetic sequences deposited in Gene Bank (accession $n^{\circ}$ M94248). The primer sets were 5'GGTCGTTCTGATGCTCTCA3' (forward) e 5'GGCTTGCT GGTTATTATCAG3' (reverse) for acrA, and 5'CGTCTAACAG TGACTCCACGG3' (forward) and 5'TTCAATCAGACC TTTACCTTC3' (reverse) for $a c r B$, and were synthesized by Life technologies, Gibco BRL (São Paulo, SP, Brazil).

DNA amplification was carried out in a $25 \mu \mathrm{l}$ volume containing high temperature lysed colony cells, $25 \mathrm{mM} \mathrm{MgCl}_{2}$ (Promega), $2.5 \mathrm{mM}$ each of the four $\mathrm{dNTP}(\mathrm{s})$, and 1 unit Taq DNA polymerase (Promega) in the proper buffer (Promega). The thermocycler PTC-100 (MJ Research) was programed for 40 cycles consisting of $94^{\circ} \mathrm{C} / 1 \mathrm{~min} ; 52^{\circ} \mathrm{C} / 1 \mathrm{~min} ; 72^{\circ} \mathrm{C} / 2 \mathrm{~min}$. The last cycle was followed by $7 \mathrm{~min}$ at $72^{\circ} \mathrm{C}$. To amplify a large fragment of approximately $2730 \mathrm{bp}$, the extension time at $72^{\circ} \mathrm{C}$ was $3.5 \mathrm{~min}$, and 1.7 units of Taq DNA polymerase were used. Negative controls were performed in all cases, as well as a positive control with $E$. coli $\mathrm{K} 12$. The products were analysed by agarose gel electrophoresis on $1 \%$ and $1.2 \%$ agarose depending on the expected amplicon length. 


\section{RESULTS}

Genetic diversity among Escherichia coli and Enterobacter cloacae

The genetic diversity of E. coli and E. cloacae isolated from the same environment, poultry carcasses, was assessed by PFGE (Fig. 1) The restriction profiles generated from XbaI hydrolysis of the total DNA of four E. coli and five E. cloacae strains were all distinct. The considered restriction fragments varied from about $50 \mathrm{~kb}$ to approximately $400 \mathrm{~kb}$. The resulting dendrogram separated $E$. coli strains from $E$. cloacae except for $E$. coli 2 , which was positioned among an $E$. cloacae cluster. All the isolates were identified by morphotinctorial and biochemical tests. Both somatic and flagellar antigens were nontyping for E. coli 2 . For technical reasons, E. coli 6 was not included in the dendrogram.

\section{Antimicrobial resistance profiles of $E$. coli and $E$. cloacae}

Table 1 shows the minimal inhibitory concentrations (MICs) of the E. coli and E. cloacae strains. Twelve antimicrobial drugs, encompassing several chemical classes, were chosen from among those used as growth promotion agents and as therapeutic drugs for broiler. The resulting MICs were determined only for the antimicrobials for which each strain was found resistant. The resistance profiles were strikingly different and correlated with the genetic results.

\section{Effect of CCCP on resistance to antimicrobials}

Table 2 shows the resistance profiles of $E$. coli and E. cloacae when cells were treated with the maximum concentration of CCCP, an energy uncoupler that does not affect the growth of each

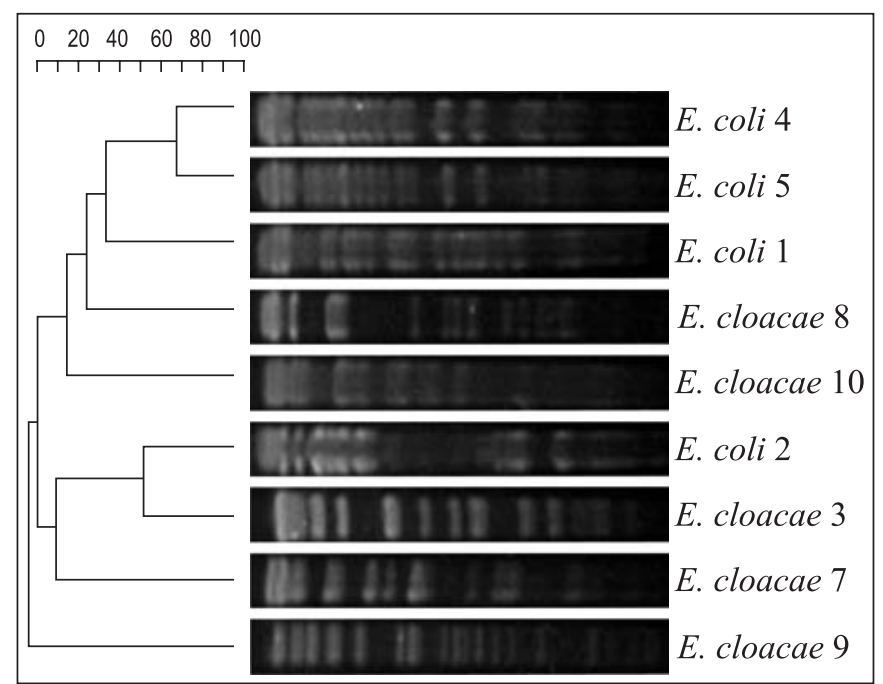

Figure 1. Dendrogam generated by Genes program, showing distances calculated by the Dice similarity of PFGE XbaI patterns among 9 pulsetypes. The degree of similarity (\%) is shown on the scale.

particular strain. For all isolates, this concentration was $20 \mu \mathrm{M}$. Only five strains, E. coli 2, E. coli 4, E. coli 6 and E. cloacae 10 , displayed lower MICs for some antimicrobials when CCCP was present, as compared to Table 1 .

E. coli 2 was more sensitive to furazolidone, nitrofurantoin, spiramycin, tetracycline, chloramphenicol, and sulfamethoxazole/ trimethoprim E. coli 4 and E. coli 6 had reduced MICs for nitrofurantoin and sulfamethoxazole/

Table 1. Minimal Inhibitory Concentrations, in BHI broth, of selected antimicrobials on Escherichia coli and Enterobacter cloacae.

\begin{tabular}{|c|c|c|c|c|c|c|c|c|c|c|c|c|}
\hline \multirow{2}{*}{ Isolates } & \multicolumn{11}{|c|}{ Antimicrobials $(\mu \mathrm{g} / \mathrm{ml})$} & \multirow[b]{2}{*}{ SXT } \\
\hline & $\mathrm{S}$ & APR & NA & CFR & CEC & Q & FR & F & SP & $\mathrm{TE}$ & $\mathrm{C}$ & \\
\hline E. coli 1 & & & & & & 30 & & 50 & & & & \\
\hline E. coli 2 & & & & 20 & & 20 & 50 & 70 & 500 & 200 & 30 & 2000 \\
\hline E. coli 4 & 250 & & 800 & & & 20 & & 80 & & & 30 & 1500 \\
\hline E. coli 5 & & & 450 & 20 & & & & & & & 20 & \\
\hline E. coli 6 & 60 & 1400 & & & & 20 & & 40 & & 2.5 & & 1800 \\
\hline E. cloacae 3 & & & & & & 30 & & & 900 & & & \\
\hline E. cloacae 7 & & & & 30 & & 30 & & & 700 & & & \\
\hline E. cloacae 8 & 30 & & 10 & 10 & & 20 & & & 400 & 2.5 & & \\
\hline E. cloacae 9 & & & & & & 30 & & & 1000 & & & \\
\hline E. cloacae 10 & 20 & & & 10 & 5 & & & & & & & \\
\hline
\end{tabular}

S: spectinomycin; APR: apramycin; NA: nalidixic acid; CFR: cefadroxil; CEC: cefaclor; CL: cefalexin; FR: furazolidone; F: nitrofurantoin; SP: spiramycin; TE: tetracycline; C: chloramphenicol; SXT: sulfametoxazol/trimetoprim and blank space: sensitive. 
trimethoprim; E. cloacae 10 had a diminished MIC for cefaclor. These results indicate energy-dependent resistance mechanisms for these drugs among those isolates. However, even though MICs for other antimicrobials or for other strains were not lowered in the presence of the uncoupler, the method used made it possible to observe that the growth of some strains was particularly impaired by some antimicrobials in the presence of CCCP (data not showed). Asterisks mark those MICs (Table 2).

\section{Presence of the acrA and acrB genes in Escherichia coli and} Enterobacter cloacae

Primers for amplification of acrA amplified fragments of expected length, about $1.1 \mathrm{~kb}$, in $E$. coli $\mathrm{K} 12$, the positive control. Primers for $a c r B$ amplified a fragment of an approximately 2.7 $\mathrm{kb}$, as expected. Results of $a c r A$ and $a c r B$ amplification are displayed in Fig. 2A and B, respectively. As expected, all E. coli were positive for these genes. Among the E. cloacae strains,

Table 2. Effect of 20mM CCCP on the Minimal Inhibitory Concentration, in BHI broth, of selected antimicrobials on Escherichia coli and Enterobacter cloacae.

\begin{tabular}{|c|c|c|c|c|c|c|c|c|c|c|c|c|}
\hline \multirow{2}{*}{ Isolates } & \multicolumn{11}{|c|}{ Antimicrobials $(\mu \mathrm{g} / \mathrm{ml})$} & \multirow[b]{2}{*}{ SXT } \\
\hline & $S$ & APR & NA & CFR & CEC & $\mathrm{d}$ & FR & $\mathrm{F}$ & $\mathrm{SP}$ & $\mathrm{TE}$ & $\mathrm{C}$ & \\
\hline E. coli 1 & & & & & & 30 & & 50 & & & & \\
\hline E. coli 2 & & & & 20 & & $* 20$ & 20 & $\leq 40$ & 450 & 150 & 20 & $\leq 1900$ \\
\hline E. coli 4 & 250 & & $* 800$ & & & 20 & & $\leq \mathbf{5 0}$ & & & 30 & 1100 \\
\hline E. coli 5 & & & $* 450$ & 20 & & & & & & & $* 20$ & \\
\hline E. coli 6 & $* 60$ & 1400 & & & & $* 20$ & & 30 & & 2,5 & & 1600 \\
\hline E. cloacae 3 & & & & & & $* 30$ & & & 900 & & & \\
\hline E. cloacae 7 & & & & $* 30$ & & $* 30$ & & & 700 & & & \\
\hline E. cloacae 8 & 30 & & $* 10$ & 10 & & $* 20$ & & & 400 & $* 2,5$ & & \\
\hline E. cloacae 9 & & & & & & 30 & & & 1000 & & & \\
\hline E. cloacae 10 & $* 20$ & & & $* 10$ & $\leq 2,5$ & & & & & & & \\
\hline
\end{tabular}

CCCP: carbonyl cyanide m-chlorophenylhydrazone; S: spectinomycin; APR: apramycin; NA: nalidixic acid; CFR: cefadroxil; CEC: cefaclor; CL: cefalexin; FR: furazolidone; F: nitrofurantoin; SP: spiramycin; TE: tetracycline; C: chloramphenicol; SXT: sulfametoxazol/ trimetoprim; *: isolates that presented lowering of growth rates without changing MIC; blank space: sensitive and; boldface: MIC reduced in the presence of $\mathrm{CCCP}$.

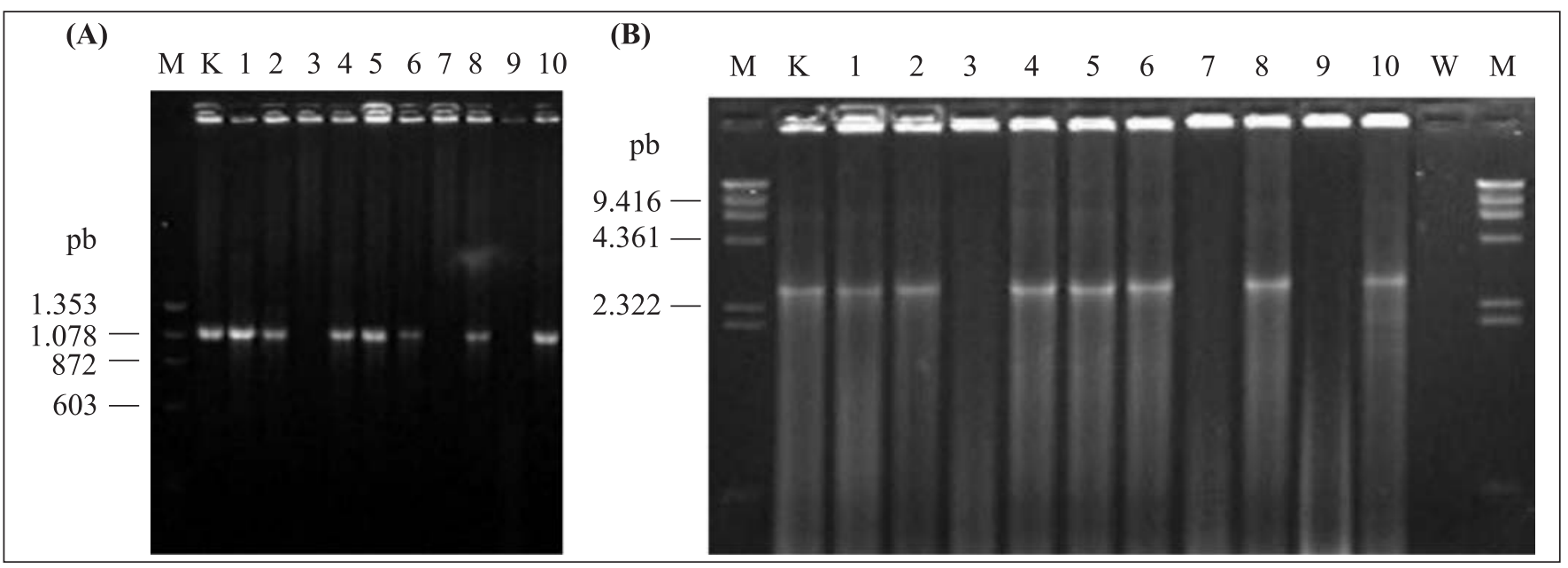

Figure 2. PCR products of $A C r A(\mathrm{~A})$ and $A c r B(\mathrm{~B})$ amplification of Escherichia coli (lines 1, 2, 4, 5 and 6) and Enterobacter cloacae (lines 3, 7 and 9) DNA. M: size marker, phage $\phi X 174 / H a e I I I$ DNA (A) and phage $\lambda / H i n d I I I(B)$; K: positive control, E coli K12 DNA PCR product; W: reaction mixture, no template (B). 
only strains 8 and 10 presented positive results, consistent for both genes.

\section{DISCUSSION}

The dendrogram generated from PFGE profiles (Fig. 1) demonstrates that the four isolates of $E$. coli are distinct from each other, as are the five E. cloacae isolates. Although the XbaI restriction endonuclease discriminated most of the isolates, i.e., $E$. coli and $E$. cloacae, this was not true for $E$. coli 2 . This strain was placed closer to the $E$. cloacae strains than to the other $E$. coli. These two species are phylogenetically very closely related among the Enterobacteriaceae family and they obviously have the same habitat, so one test alone may not be sufficient to discriminate between some of the strains $(8,31)$. Polyphasic taxonomy takes into account phenotypic, ecological and genetic data and integrates all information to yield a more precise and trust worthy identification and classification of the strains (8).

The diversity among individuals in the isolated groups was also observed by their resistance profiles and the different MICs before (Table 1) and after adding CCCP (Table 2) for each antimicrobial tested. The different resistance levels observed among the isolates suggests diverse combinations of strategies. This would pose a problem because bacteria of the same source could be acquiring different resistance genes for the same antimicrobial, thus diversifying the pool of resistance determinants. E. coli 2 , a multiresistant strain, had a completely distinct resistance profile when compared to all E. coli and $E$. cloacae strains tested.

All the antimicrobial agents were represented at least once in the resistance profiles of the strains. Apramycin, cefaclor and furazolidone appeared only once in the resistance models (Table 1). Cefalexin resistance was the most prevalent, being present in eight isolates, followed by resistance to cefadroxil and espiramycin, both represented five times (Table 1). Cefalexin and cefadroxil are both beta-lactams and first generation cephalosporins (16). Cefaclor is a second generation cephalosporin (16); it is understandable why more strains are resistant to those drugs, which have been used for a longer time. The most frequent mechanism of resistance to beta-lactam is possibly the presence of beta-lactamases, enzymes that hydrolyze the amide bond at the beta-lactam ring (16). If this is the case, there is also a diversity of beta-lactamases because the resistance profiles did not coincide in all isolates when this class of antimicrobials was considered. The lowering of the MIC or of growth rates in the presence of the antimicrobial drugs and the uncoupler CCCP for all isolates, except for $E$. coli 1 and E. cloacae 9 (Table 2), suggest a PMF-dependent resistance mechanism. E. coli 2 is a good candidate for MDR studies (Table 2) and diversity (Fig. 1).

As expected, oligonucleotide primers designed to amplify genes of the $a c r A B$ operon yielded positive results with all the
E. coli isolates (Fig. 2A and B). The AcrAB multidrug efflux system is the main efflux pump in $E$. coli and it is responsible for the acquisition of multiple antimicrobial resistance, including resistance to tetracycline, chloramphenicol, fluoroquinolones, fusidic acid, lipophilic beta-lactams antibiotics, nalidixic acid, novobiocin and rifamicin $(21,22)$. E. coli 2, 4, 5 and 6 displayed PMF-dependent resistance mechanisms as far as nalidixic acid, tetracycline, cefalexicin and chloramphenicol were concerned (Table 2). PMF is the source of energy for the transport proteins AcrA and AcrB (11). It is possible that in the tested isolates, the AcrAB system was responsible for the PMF-dependent resistance observed.

Among the five $E$. cloacae isolates, two (isolate numbers 8 and 10) tested positive by PCR for both genes $a c r A$ and $a c r B$ (Fig. 2A and 2). The efflux system AcrAB has been identified in E. cloacae from human sources (14) and from poultry sources (19). The genes encoding acrAB-tolC efflux pumps were identified in the nosocomial pathogen Enterobacter aerogenes (26). An increased in AcrA protein was observed in clinical isolates of imipenem-resistant E. cloacae (4). E. cloacae 8 and 10 displayed PMF-dependent resistance to nalidixic acid, tetracycline, cefadroxil, cefalexin, and cefaclor (Table 2). These antimicrobials are substrates of the AcrAB multidrug efflux system. Besides the known substrates of the AcrAB system, other antimicrobials were found to possess some PMFdependent resistance mechanisms (Table 2). Phenotypic and genotypic tests revealed the possible presence of the AcrAB system (Table 2, Fig. 2A and 2B). This system could possibly transport other antimicrobials of different classes, such as spiramycin, furazolidone, nitrofurantoin, sulphametoxazol/ trimetoprim (Table 2), or there may be other systems functioning simultaneously. DNA sequencing and mutant analysis may bring some light to this issue. Amplifications of AcrA or AcrB was observed in E. coli 1 (Fig. 2A and B), but the PMF-dependent resistance phenotype was not detectable (Table 2). Synergism among resistance mechanisms has been reported (24) and the AcrAB system is constitutively expressed (17). So, it is possible that this MDR could be functional but at very low levels that are undetectable by the methods used here.

While many studies have evaluated resistance in bacterial pathogens, relatively few have looked at commensal bacteria. These bacteria are present in the agricultural environment in numbers far greater than pathogens; they are major players in the harboring and disseminating of antibiotic resistance genes $(1,28)$. Such a diversity of resistance models and possible resistance mechanisms detected in so few isolates from the same source not related to pathogenic serotypes may indicate an important public health issue concerning commensal bacteria in food animals. E.coli and E. cloacae are inhabitants of the gastrointestinal tract of humans and animals $(10,12)$. While $E$. coli is widely studied as a food pathogen, E. cloacae has emerged as an important nasocomial pathogen with numerous 
outbreaks of infections being reported (15,27). Bacteria of animal origin may reach human beings through several routes and genetic determinants of resistance may transfer to the human microbiota and diffuse to different geographic areas $(5,29)$.

The five E. coli isolates and six E. cloacae isolates, apparently a small sample, were all different strains, a fact that stresses the ample diversity among these bacteria as far as drug resistance mechanisms are concerned.

\section{ACKNOWLEDGEMENTS}

This research was supported by Fundação de Amparo a Pesquisa do Estado de Minas Gerais (FAPEMIG) and Coordenação de Aperfeiçoamento de Pessoal de Nível Superior (CAPES), Brazil.

\section{RESUMO}

\section{Sistemas de efluxo multidroga em Escherichia coli e Enterobacter cloacae obtidas de carcaças de frangos sadios}

Os membros da família Enterobacteriaceae estão presentes no intestino do homem e dos animais como comensais ou agentes causadores de doença importantes. Bactérias multirresistentes podem possuir sistemas de efluxo multidrogas (MDR) sendo capazes de sobreviver em nichos ecológicos adversos. Escherichia coli e Enterobacter cloacae, multirresistentes, isoladas de frangos sadios foram investigadas quanto à presença de MDR. A diminuição da concentração inibitória mínima de antimicrobianos, na presença de um desacoplador da força próton motora (PMF), foi usada para detectar o fenótipo MDR. Foi realizada PCR dos genes codificadores de AcrA e AcrB, componentes de um sistema MDR. A diversidade de cada isolado foi confirmada por eletroforese em gel de campo pulsado (PFGE) usando a endonuclease $\mathrm{X} b a \mathrm{I}$. Observou-se em todos os isolados, exceto $E$. coli 1 e E. cloacae 9, uma diminuição das MICs ou das curvas de crescimento na presença dos antimicrobianos, indicando um mecanismo de resistência dependente da PMF. Os produtos amplificados esperados derivados de $a c r A B$ foram obtidos em todos os isolados de E. coli e em dois, dos cinco, de E. cloacae. O dendrograma gerado mostra diferentes perfis de bandas (pulsetypes), confirmando a diversidade genética entre os isolados. Uma questão importante e relacionada à saúde publica é o fato de que diferentes modelos e mecanismos de resistência aos antimicrobianos estão presentes em um número reduzidos de isolados não patogênicos e obtidos de uma mesma origem. Esses podem ser fontes de genes de resistência para outros microorganismos, entre eles, cepas patogênicas.

Palavras-chave: multirresistência; antimicrobianos; Enterobacteriaceae; força próton motora; diversidade

\section{REFERENCES}

1. Aarestrup, F.M. (1999). Association between the consumption of antimicrobial agents in animal agents in animal husbandry and the occurrence of resistant bacteria among food animals. Int. J. Antimicrob. Agents. 12, (4) 279-285.

2. Al-Mayah, A.A.S.; Al-Ahmed, J.A. (2005). Influence of antibiotics treatment on hematological aspect in chicken. Int. J. Poul Sci. 4 (5): 323-325.

3. Angulo, F.J.; Nunnery, J.A.; Bair, H.D.; (2004). Antimicrobial resistance in zoonotic enteric pathogens. Rev. Sci. Tech. Off. Int. Epiz. 23 (2), 485-496.

4. Bornet, C.; Chollet, R.; Mallea, M.; Chevalier, J.; Davin-Regli, A.; Pagés, J.M.; Bollet, C.; (2003). Imipenem and espression efflux pump in Enterobacter aerogenes. Biochem. Biophys. Res. Commun. 301 (4), 985-990.

5. Bywater, R.J.; Deluyker, H.; Deroover, E.; Jong, A.; Marion, H.; McConville, M.; Rowan, T.; Shryock, T.; Shuster, D.; Thomas, V.; Vallé, M.; Walters, J. (2004). A European survey of antimicrobial susceptibility among zoonotic and commensal bacteria isolated from food-producing animals. J. Antimicrob. Chemother. 54 (4), 744754.

6. Casewell, M.; Friis, C.; Marco, E.; McMullin, P.; Phillips, I. (2003). The European ban on growth-promoting antibiotics and emerging consequences for human and animal health. J. Antimicrob. Chemother. 52, (2) 159-161.

7. Chang, N.; Chui L. (1998). A standardized protocol for the rapid preparation of bacterial DNA for Pulsed-Field Gel Electrophoresis. Diagn. Microbiol. Infect. Dis. 31 (1), 275-279.

8. Colwell, R.R. (1970). Polyphasic taxonomy of bacteria. In: Lizuka, H.; Hazegava, T. (Eds.). Culture Collections of Microorganisms. University of Tokyo Press, Tokyo, p. 421-436.

9. Cruz, C.D. (1998). Programa GENES-Aplicativo Computacional em Estatística Aplicada à Genética. Genet. Mol. Biol. 21, (1) 135138.

10. Escobar-Páramo, P.; Grenet, K.; Le Menac'h, A.; Rode, L.; Salgado, E.; Amoren, C.; Gourion, S.; Picard, B.; Rahimy, M.C.; Andremont, A.; Denamur, E.; Ruimy, R. (2004). Large-scale population structure of human commensal Escherichia coli isolates. Appl. Environ. Microbiol. 70 (9), 5698-5700.

11. Eswaran, J.; Koronakis, E.; Higgins, M.K.; Hughes, C.; Koronakis, V. (2004). Three's company: component structures bring a closer view of tripartite drug efflux pumps. Curr. Opin. Struct. Biol. 14 (6), 741747.

12. Hartl, D.L.; Dykhuizen, D.E. (1984). The population genetics of Escherichia coli. Annu. Rev. Genet. 18, 31-68.

13. Lewis, K. (1994). Multidrug resistance pumps in bacteria: variations on a theme. Trends Biochem. Sci. 19 (3), 119-123.

14. Linde, H.J.; Notka, F.; Irtenkauf, C.; Decker, J.; Wild, J.; Niller, H.H.; Heisig, P.; Lehn, N. (2002). Increase in MICs of ciprofloxacin in vivo in two closely related clinical isolates of Enterobacter cloacae. J. Antimicrob. Chemother. 49 (4), 625-630.

15. Liu, S.C.; Lue, H.S.; Yen, M.Y.; Lee, P.I.; Chou, M.C. (2002). Study of an outbreak of Enterobacter cloacae sepsis in a neonatal intensive care unit: the application of epidemiologic chromosome profiling by pulsed-field gel electrophoresis. Am. J. Infect. control. 30 (7), 381-385.

16. Mason, I.S.; Kietzmann, M. (1999). Cephalosporins - pharmacological basis of clinical use in veterinary dermatology. Vet. Derm. 10 (3), 187192.

17. Mazzariol, A.; Cornaglia, G.; Nikaido, H. (2000). Contributions of the AmpC $\beta$-lactamase and the AcrAB multidrug efflux system in intrinsic resistance of Escherichia coli K12 to $\beta$-lactams. Antimicrob. Agents Chemother. 44 (5), 1387-1390. 
18. Moreira, M.A.S.; Oliveira J.A.; Teixeira, L.M.; Moares, C.A. (2005). Chloramphenicol efflux system in Escherichia coli isolated from poultry carcasse. Vet. Microbiol. 109 (1-2), 75-81.

19. Moreira, M.A.S.; Souza, E.C.; Moraes, C.A. (2004). Multidrug efflux systems in Gram-negative bacteria. Braz. J. Microbiol. 35 (1-2), 1928.

20. Nikaido, H. (1996). Multidrug efflux pumps of Gram-negative bacteria. J. Bacteriol. 178 (20), 5853-5859.

21. Nikaido, H.; Basina, M.; Nguyen, V.Y.; Rosenberg, Y. (1998). Multidrug efflux pump AcrAB of Salmonella typhimurium excretes only those $\beta$-lactam antibiotics containing lipophilic side chains. $J$. Bacteriol. 180 (17), 4686-4692.

22. Okusu, H.; Ma, D.; Nikaido, H. (1996). AcrAB efflux plays a major role in the antibiotic resistance phenotype of Escherichia coli multipleantibiotic-resistance (Mar) mutants. J. Bacteriol. 178 (1), 306-308.

23. Piddock, L.L.V. (2006). Multidrug-resistance efflux pumps-not just for resistance. Nat. Rev. Microbiol. 4 (8), 629-636.

24. Poole, K. (2001). Multidrug resistance in Gram-negative bacteria. Curr. Opin. Microbiol. 4 (5), 500-508.

25. Poole, K. (2004). Efflux-mediated multiresistance in Gram-negative bacteria. Clin. Microbiol. Infec. 10 (1), 12-26.
26. Pradel, E.; Pagés, J.M. (2002). The AcrAB-TolC efflux pump contributes to multidrug resistance in the nosocomial pathogen Enterobacter aerogenes. Antimicrob. Agents Chemother. 46 (8), 2640-2643.

27. Sanders Jr, W.E.; Sanders, C.C. (1997). Enterobacter ssp: pathogens poised to flourish at the turn of the century. Clin. Mirobiol. Reviews. 10 (11-12), 220-241.

28. Smith, D.L.; Harris, A.D.; Johnson, J.A.; Silbergeld, E.K.; Morris Jr, G.J. (2002). Animal antibiotic use has an early but important impact on the emergence of antibiotic resistance in human commensal bacteria. Proc. Natl. Acad. Sci. USA. 99 (9), 6434-6439.

29. Van Den Bogaard, A.E.; Stobberingh, E.E. (2000). Epidemiology of resistance to antibiotics links between animals and humans. Int. J. Antimicrob. Agents 14 (4), 327-335.

30. Van Den Bogaard, A.E.; London, N.; Driessen, C.; Stobberingh, E.E (2001). Antibiotic resistance of faecal Escherichia coli in poultry, poultry farmers and poultry slaughterers. J. Antimicrob. Chemother. 47 (6), 763-771.

31. Vandamme, P.; Pot, B.; Gillis, M.; Vos, P.; Kersters, K.; Swings, J. (1996). Polyphasic taxonomy, a consensus approach to bacterial systematics. Microbiol. Rev. 60 (2), 407-438. 